\title{
Contemporary Challenges of Democratisation and Development in Africa
}

\author{
Kehinde Olayode, PhD \\ Department of International Relations Faculty of Administration Obafemi \\ Awolowo University Ile-Ife, Osun State NIGERIA
}

doi: 10.19044/esj.2016.v12n28p146 URL:http://dx.doi.org/10.19044/esj.2016.v12n28p146

\begin{abstract}
The end of the cold war and the triumph of liberalism after the collapse of the Soviet Union had a reverberating effect on the wave of democratisation that swept through most parts of the developing world, including Africa. In spite of the euphoria of the third wave of democratisation, the economic condition in Africa looks grim. Africa's traditional importance as a supplier of raw materials has diminished with competition from synthetic substitute and suppliers in Asia, Latin America and the former Soviet Republics. Also, in the current wave of massive capital movements to the 'emerging markets', Africa remains marginal. The paper argues that while democracy is usually seen as a 'harbinger of development', it is also recognised that the enthronement of democracy becomes more improbable in a harsh economic environment. This is to say that while democracy enhances development, it is in itself distressed by acute poverty, which threatens the very survival of individuals. While transitions towards democracy do not guarantee rapid economic development and improved human right situations, democracy should however create a window of opportunity where groups struggling for development and human rights would have better possibilities than before for realising their demands. Concluding, any efforts by Western donor countries or the IMF and the World Bank to impose political conditionality to encourage democratisation in Africa will result in mere window dressing. There is also the possibility of unstable democracies arising from a conflict between those who want to complete the democratisation process and those who want to halt it for failing to deliver the much-desired goods. The paper is a review of dynamism of contemporary democratic movements amidst different challenges in Africa. It is undertaken exploring different perspectives through desk review, theoretical interrogations and analysis of relevant data.
\end{abstract}

Keywords: Democratisation, Economic Development, Poverty, Africa 


\section{Introduction}

The global wave of democratisation that swept through most parts of the developing world in the late 1980s and early 1990s revived the intellectual discourse on the linkage between democracy and development. The global democratic wave has a tremendous impact on the political landscape of Africa. Unlike in the previous past, military dictatorship is now an exception rather than the rule in contemporary Africa. External pressures from International Financial Institutions (IFIs), global civil society and local domestic forces combined together to provoke far-reaching political liberalisation across the continent of Africa. Previously, the exegeses of the cold war had stifled the voices of local forces agitating for democracy as the dynamics of the super power confrontations made Africa a fertile ground for breeding sit-tight dictators who enjoyed unfettered political patronage in exchange for allegiance to different super powers. Many African dictators exploited the advantage of the super power rivalries to receive massive financial, diplomatic and military supports through which they strengthen their stranglehold on political power and elongated their tenure to the constellation of popular democratic forces (Olayode, 2013).

However, the end of the cold war clearly exposed the fragility of many African dictators as the withdrawal of the super power supports clearly weakened them, making them highly vulnerable to popular democratic forces. The argument concerning the primacy of internal factors behind the democratic movements underscores the strength of domestic political protests and pro-democracy movements stirred and energized by the failures of development project, the economic crises of the 1980s and 1990s, and the disintegration of the postcolonial state's legitimacy and capacity. They also highlight the demonstration effects of regional transitions, such as Benin in Francophone West Africa, Zambia in Southern Africa, the Palestinian Intifada for Arab Spring in North Africa, and the dismantling of Apartheid regime in South Africa for continental inspiration. Those who emphasize external forces point to the decisive impact of the end of the Cold War, the demonstration effects of the collapse of communism in Eastern Europe, and the imposition of structural adjustment programs and political conditionalities by Western bilateral and multilateral financial institutions (Barkan, 2009).

The 1980s and 1990s'democratisation represented a period of struggles for the "second independence"; the "first independence" was fought for in the 1950s and 1960s-the era of decolonisation. Thus, African democratic struggles are linked to, structurally and symbolically, the rich reservoirs of earlier struggles against exploitation and oppression. The current marginalization of Africa in the global hierarchy as well as debilitating governance deficit provides popular forces with added impetus 
for democratization struggles with a dual purpose of economic emancipation and socio-political justice. Central to an 'emancipatory' project is the development of a strong, democratic and activist state that asserts its development role within the context of a commonly shared national development vision with strong support from the population.

There is no doubt that democratisation is an exciting project on the continent of Africa due to the liberalization of the political space and the opportunities given to previously repressed constituencies and marginalized groups to express their views and be incorporated into the political mainstream. A major achievement of democratisation in Africa is the presence of enabling environment to articulate political alternative political programmes. In many countries such as Nigeria, Togo, Kenya, Malawi and Benin Republic, many notable politicians who had previously been on exile have returned to participate in open transitional processes. There have also been a considerable reduction of political repression and a relative atmosphere of freedom to express dissenting views now pervades the political environment. While the press is not completely free as occasional cases of intimidation and repression have occurred, there is a greater degree of freedom for the press in many African countries now unlike the experiences of the past.

Democratisation has also opened the face for the articulation of development issues as affecting vulnerable groups in the society such as children, women, rural dwellers, minority groups, the poor and physicallychallenged. Also environmental issues such as global warming, pollution, deforestation, among others have been pushed to the top burner of global agenda in recent times. The new democratic dispensation in Africa, with emphasis on greater transparency, accountability and good governance, has opened new vistas for the engagement of Non Governmental Organisations (NGOs), and Civil Society Organisation (CSOs) in various facets of development. Most development works at the grassroots are carried out by NGOs, CSOs, and their respective coalition groups, especially in such sectors as - health, education, environment, and agriculture and rural development.

African continent continues to play the role of an unequal partner in the areas of trades, industrialization, technology development, learning and applications. This has reinforced the north-south divide in the effects of globalization, with attendant implications for socio-economic conditions of the African states, communities and households.

Generally, the developing nations are not only disadvantaged against the developed nations, the individuals and groups within them are further disadvantaged. Various development paradigms imposed on Africa have had little or no regard for the continent's indigenous knowledge. The persistent 
'cut and paste' approach of adopting other foreign model of governance, economic strategic, education and cultural values have failed to understand African's unique challenges and address same with indigenous resources and easily accessible home grown tools. Since independence, Africans have been made to believe, rather erroneously, that they are fundamentally lacking in the innate ability to generate ideas, mould them into reality and implement same for the development of the continent.

Against this background, this paper examines some of the contemporary challenges of the democratisation process in Africa. The paper argues that while democracy is usually seen as a 'harbinger of development', it is also recognised that the enthronement of democracy becomes more improbable in a harsh economic environment. This is to say that while democracy enhances development, it is in itself distressed by acute poverty, which threatens the very survival of individuals. While transitions towards democracy do not guarantee rapid economic development and improved human right situations, democracy should however create a window of opportunity where groups struggling for development and human rights would have better possibilities than before for realizing their demands. If democratisation is to be firmly anchored in African societies, the initiative towards democratisation should remain in the hands of domestic social forces. Fundamental to this endeavour is the need to build a functioning and effective state that responds to the concerns of its citizens and articulates a common national development vision unconstrained by the remote forces of neoliberal globalization (Fantu 2012:265-267).

While democracy as a global vision may be desirable; however, the extent to which substantial local realities are reflected therein is minimal. How can Africa meaningful engage with the global world to ensure that African realities are reflected in 'global vision'? What are the current bargaining strengths possess by Africa to maximize her gains in strategic negotiations with the rest of the world? These are some of the interrogative questions explored in the paper.

\section{Theoretical and Conceptual Interrogations}

The dominant development framework of neoliberalism presents a positive correlation between democracy and development based on the assumption that economic liberalisation cannot be sustained without liberalising the political structures of the state (Harrison 2005:1315, Bond and Margaret 1999:480). These changes are understood as multi-party elections, respect for fundamental human rights and the rule of law. It implies an underlining capitalist economic logic to the global democracy movement that placed the interest of global capital above people's interest whose development is really at issue (Olayode 2013: 18-21). 
Democracy and Democratisation emerged as the new liberal concept developed in the post-Cold War order for analysing international development. The new discourse privileges democracy and politics as the necessary precursor of economic development. A consensus arrived by international donor agencies and western powers was that democracy, through multi-party politics and regular 'free and fair elections' was a precondition for 'good governance' (Adejumobi 2000: 4). Democracy as a measure of good governance gained primacy in a global environment in the post-Cold War order in which socialism had received enormous setbacks, leaving the ideological high ground mainly to neo-liberal perspectives of the market and governance (Adejumobi, 2000:5).

Most countries expected democracy to usher in significant economic assistance, lending, debt-relief and investment. It was an era of considerable optimism as demonstrated by Francis Fukuyama's 'End of History Thesis', in which international society will finally been brought to accord with Western liberalism values. Fukuyama in the thesis prematurely and in a triumphant manner declared Francis Fukuyama decline of communism and the collapse of the 'Soviet Union' as 'the end of history' and as such, 'the end point of mankind 's ideological evolution and the universalization of Western liberal democracy as the final form of human government' (Fukuyama, 1992:42). The prevailing liberal argument in the immediate post-Cold War order was that liberal democracy provides the basic foundation for economic development. The liberal values like freedom of speech and association, the rule of law, multi-party politics, and elections, the protection of human rights and separation of powers were assumed to create the institutional context and process for economic development.

Due to cultural variations across the world, non-western people perceive focus on western political cultures as criticism against their own cultural values. However, taking into consideration the dominant democratic models and institutions on the global level, that follow the western model, it is necessary to identify certain values and psychological propensities which favour and sustain democracy. Thus, emphasis on such cultural attributes may amount to painting a western image of democracy.

The globalisation of the democractic movement emerged as the distinctive feature of the post-Cold War international system in a global environment in which 'socialism had received enormous setbacks, leaving the ideological high ground mainly to neo-liberal perspectives of the market and governance' (Adejumobi, 2000:4). Persistent linkages were being drawn to correlate democracy and economic development using liberal economic theoretical analysis. Many dictators in the developing world, especially Africa, were forced to embrace political pluralism as foreign aids, economic investment and technological assistance were tied to progress in political 
liberalism. The overwhelming ideological and intellectual dominance of neo liberalism and neo classical interpretation of the nature and performance of African economies have persuaded leading actors in the democratisation process that there is no alternative to orthodoxy.

The neo-liberal assumptions that the market reforms would promote liberalisation at the social and political levels have not been borne out by the evidence from many African countries. Although conditionality has certainly increased the tempo of pressures for democratisation, the state authorities perceived such pressures as obstructive of their economic reforms. The implementation of structural adjustment policies and the privatisation of the state increased social appropriation and accumulation for the political elites and at the same time led to abdication of the state from its social responsibilities.

For the purpose of this paper, democratisation is broadly conceived as a multi faceted process that leads to the 'construction of a stable democratic system of governance, incorporating such elements as political participation, economic and social justice, free and fair elections' (Nwabueze 1999: 8). Nwabueze's stated thesis is that democratisation requires that the society, economy, politics, the constitution of the state, the electoral system and the practise of the government be democratised. The process of democratisation begins with political challenges to authoritarian regimes, advances through the political struggles over liberation, and requires the installation of a freely elected government. It concludes only when democratic rules becomes firmly institutionalised as well as valued by political actors at large

\section{Contemporary Democratisation in Africa}

The global wave of democratisation that swept through most parts of the developing world in the late 1980s and early 1990s, especially after the end of the Cold War has left an indelible mark on the continent of Africa. Although local forces for political reforms had been a continuous feature of Africa society through the colonial period to the post-independence era, a favourable atmosphere was created after the collapse of Soviet Union that complemented and assisted the domestic forces, already agitating for political and economic reforms. The implementation of varieties of structural adjustment programmes with their excruciating impact on the local population, elicited widespread resistance, sometimes violent opposition, and demand for socio-economic and above all, political changes in the form of multi-party politics. Democratisation process has two important features in Africa. The first is that it is mainly a mass movement of the dominated classes, and the second is that it is a human rights movement for civil liberty. As demonstrated in several experiences, the harsh response of the 
authoritarian state to such movements through arbitrary detention, martial and special courts, emergency regulations and state security acts, news blackout and censorship of the press; has only served to widen the democratisation struggle by enlisting new forces. Democratic struggle became a mass movement after the collapse of communism in what has often been referred to as ‘the third wave of democratisation' (Huntington, 1991).

Contemporary democratic movement in Africa is a continuation of the original nationalist struggles against imperialism, neo-colonialism, and for accountability, good governance and the empowerment of the masses. The movement is a vehicle for attaining deeper political and economic goals that would address the basic problems of the people and liberate them from the clutches of hardship, exploitation, marginalisation, oppression, and dictatorship. Initially, popular struggles in many African countries in the 1980s have had little to do with political demands but were concerned with securing relieves from the social contradictions and hardships created by economic hardship. The opposition was based on the constitutive interests of various organisations -higher salaries and better working conditions for labour union and workers, better campus conditions and lower fees for students, lower rents for market stalls for market woman, and so on. However, the emergence of human rights and pro-democracy organisations specifically to demand political reforms, the inspiration from political struggles in other parts of the world, and support from members of the international community led to expedient and transient coalition formation for political agitation towards multi-party democracy.

The human rights movements recognised that the root cause of human rights abuses in Africa came from non-responsive governments, able to muscle through their political, economic, and social agendas without effective 'legal challenge'. By clamping down harshly on political opponents, African dictatorial regimes undercut human rights protection. It was the overweening obstacle. Without democratisation, restoration of the rule of law, transparency and accountability in government operations, and the like, the human rights situation in Africa remained seriously flawed. It appeared clearly that human rights movements couldn't stand aside from politics. Thus, the forces unleashed by the implementation of structural adjustment policies, coupled with the increased repression of civil society by successive military dictators, stirred human rights movement into demands for democratic reforms.

Contemporary democratic movement has enabled various groups to assert their rights and resist authoritarian regime, and install democratic government in many African countries. These struggles enabled fledging civil society coalitions to blossom, thereby strengthening their efficacy. 
However, the deep polarisation in many multi-ethnic societies at the same time has destabilised fragile peace in many parts of Africa.

\section{Contemporary Challenges of Democratisation in Africa}

The contemporary global order has undergone deep transformation from the immediate Post-Cold War Order when the third wave of democratisation swept through most developing world. There was relative stability, prosperity and coherence from the late $20^{\text {th }}$ century through the early $21^{\text {st }}$ century. The economies of western countries were on the rise and the conditions favourable for promoting democracy and development. However, the global world in 2016 is currently encountering more complex challenges of climate change, population pressures, increasing urbanisation, multi-polar world and increasing polarization of the global order along development and technology lines. Within the global order, the distribution of poverty demonstrates huge inequities across different population groups and fragile states. In the developing world, over 1.2 billion people were largely off the track to meet the MDGs. Furthermore, the current period is characterised by multiple crisis, instability and terrorism. Thus, a post MDG development agenda must address the issues of food security, youth challenges, climate change, violence, corruption, governance and leadership (Aleyomi, 2013).

Africa's central political economy dilemma at the beginning of the $21^{\text {st }}$ Century is the successful consolidation of democracy in the face of persistent and often unmanageable demands from many sections of society. The immediate economic agenda is stabilization to reduce massive deficits, mobilisation of aid, including debt rescheduling, and initial steps to counter deteriorating living standard and physical infrastructure (African Development Bank, 2014). Without showing some progress, new governments are unlikely to retain power for long, possibly opening the way for renewed authoritarian rule or even state collapse.

The overarching leadership of the Breton Wood Institutions and the Western powers in conceptualising and dictating the direction of the 'governance' and 'developmental' debate tends to preclude the possibility of critical interrogating the role of these institutions in promoting development through the various neoliberal schemes imposed on many African countries, especially strategies centre on deregulation, and adjustment policies (Bendana 2014:2). A critical interrogation of governance is important because it influences not only the mechanisms but also strategies and ideological underpinnings about development and the means to achieve greater economic democracy (Mundy, 2007) While 'governance' has been repeatedly presented as the missing link to sustainable economic growth and development, including the attainment of MDGs in Africa, however, the 
notion of 'good governance' being promoted by western powers and their multilateral agencies is not the one that is people-centred but rather entails the logic of placing the state and society at the mercy of unfettered free market. This is with the assumption that economic growth alone is synonymous to development. Elimination of poverty and hunger, while truly a desirable goal will continue to remain elusive without a democratisation of the processes, mechanisms and the operations of multilateral institutions and global governance (Bendana 2014:1). This is a critical issue of interrogation for the post-2015 development agenda and the central argument of this paper.

The most immediate threat to democratic consolidation in Africa is likely to be the disastrous economic situation that already contributed to the de-legitimisation of previous governments. New democratic regimes are thus faced with the daunting tasks of consolidating democratic institutions and undertaking urgent economic reforms simultaneously.

There is also the urgent need for the reform of multilateral global governance, which is not only undemocratic but highly repressive and exploitative to the developing world. The global environment for the advancement of democracy has become more complex. The desire for democratic governance by people of all cultures needs to be reinforced by a democratised multilateral system, which is essential for the strengthening of the international rule of law, and by developing multifaceted responses to religious and other forms of extremism which pose threats to the advancement of democracy (Higgot, 2005).

The aspirations of the Africans are not only confined to the arena of political democracy (of elections and granting of civil and political rights), but also involve the demand for economic empowerment, better living standards, and adequate social welfare. Indeed, for the majority of the people, democracy is meaningful only when it delivers socio-economic goods. As Claude Ake astutely pointed out, 'ordinary Africans do not separate political democracy from economic democracy or for that matter from economic well being' (Ake, 1999:210). In other words, political democracy must be accompanied by socio-economic development. The deteriorating socio-welfare and living standards of the people in spite of 'electoral democracy' is gradually undermining the confidence of the populace in the new democratic order (Simelane and Chiroro, 2013).

Economic democracy must be central in Africa's efforts to democratise. Improved economic and social conditions represent a cardinal need and paramount desire of contemporary Africans. For them, democracy in the villages begins with breakfast. To them, rights mean access to education, health services, and bacteria-free water. Individuals, groups and collectives in society must be guaranteed a minimum level of economic 
security, to empower them to become full and active participants in political and economic decision-making. Otherwise, extreme levels of poverty will effectively bar the most vulnerable-women, children and minority ethnic groups from shaping their destinies. Therefore, economic rights and social justice must be rooted in collective responsibility; otherwise, democracy will be severely compromised and weakened. Extreme levels of poverty can effectively bar the marginalized from meaningful participation in society. Under such a state of affairs, 'economic democracy' could in turn make the 'freedoms accompanying multi-party politics a farce (Ake, 2000).

The nature and constitution of democracy determines the extent to which the people participate concretely in decision-making, beyond elections, and how their collective efforts influence their life chances. Democracy in its constituted elements must give practical expression to an organised and predictable life for the people, engender equity and fairness, both in power and resource distribution, and facilitate the empowerment of the people. It is through this that democracy can provide a base for socioeconomic development. Democracy itself stands better chances of consolidation where there is satisfactory human development. It is not possible to attain high levels of participation and empowerment in the development and political processes where illiteracy and unemployment are high, where education is lacking, and gender inequalities are glaring. The consolidation of democracy and good governance should simultaneously contribute to stronger foundations for sustainable development (Ake, 1996; Ake; 2000).

Furthermore, the current democratic transitions in Africa are posing critical and complex issues of constitutional control and reform of security structures on the continent. While armed forces and other security agencies are often weak and politically discredited, they nevertheless continue in many countries to command more than sufficient power to assert their autonomy of both government and society, and even overturn elected governments. On the other hand, the deteriorating state of security and human rights on the continent in recent years suggests that security agencies are ill-equipped to execute their mandate of protecting society.

In Africa, with few exceptions, issues of national defence and public security have not attracted nearly the level of public and policy debate, or scholarly attention that the subject matter deserves. This is particularly true of their implications for democratic consolidation. In most countries, weak capacity to implement civil control has combined with low professionalism and operational effectiveness of the armed forces and security agencies to make this a difficult and volatile area for emerging democracies. Therefore, restructuring of African security agencies is urgently required to enhance both professionalism and civil control and accountability (Howe, 2001). 


\section{Prospects for Democratisation in Africa}

The prospects for democratisation are very optimistic for Africa today given the institutional reforms undertaken by the African Union (AU) and other regional economic communities like ECOWAS in the areas of peace building, security reforms, democracy and good governance. There is no denying the reality that that has been a steady progress in the areas of democratic stability, good governance and development in Africa in the last two decades. Dictatorial governments are now the exceptions rather than the rule of the game on the continent today. There is also increasing involvement and engagements with civil society organisations in the areas of conflict resolution, post-conflict reconstruction and peace building. The AU and ECOWAS have grown and still growing in capacity and sophistication in the areas of security and peace building. Several legal and institutional frameworks have been established to address the challenges of human security, governance and sustainable development. While security threats are still surfacing in Africa, like other regions, there are adequate institutional frameworks to address them unlike what obtained in the Liberian and Sierra-Leonean crises (International Crisis Group, 2004).

However, to consolidate these achievements, Africa leaders must continue to deepen democratisation through good governance, political tolerance, transparency and accountability in governance. Civil society actors must also remain vigilance to act as watchdog to expose dictatorial leaders and political excesses. A sustainable economic growth and institutional reforms are also needed to improve quality of life that will prevent relapsing into resource-starved and poverty induced conflicts. The narrow resource and raw-material based economic orientation is highly susceptible to the fluctuations of global market, as currently experienced in the global crisis in the oil market (ILO, 2010).

Africa's prospects for democratic consolidation are definitely not hopeless but not assured. It is unrealistic to think that emerging democracies can suddenly reverse course and institutionalise stable democratic government simply by changing leaders, constitutions, or public mentality. Progress towards democratic consolidation is likely to be gradual and slow, with many imperfections along the way.

The task of restructuring civil-military relations also requires a total de-militarization of the national psyche through civic education, massive public enlightenment programmes, supremacy of the rule of law, strengthening of democratic institutions, respect for human rights, and the elevation of democratic values into national life.The ultimate challenge, however, is to advance democracy in a way that is dynamic, and relevant to the existential needs of the people. The deteriorating economic situations 
could create the kind of disaffection that the military has exploited in the past to destabilise democratic regimes.

While democracy is usually seen as a 'harbinger of development', it is also recognised that the enthronement of democracy, even at the level of internal organisation of civil society, becomes more improbable in a harsh economic environment. This is to say that while democracy enhances development, it is in itself distressed by acute poverty, which threatens the very survival of individuals. Since the natural tendency is for human beings to be brutal and desperate when their survival is at stake, a society desirous of sustained democracy should be in a position to guarantee minimum economic subsistence to its citizens.

The globalization of civil society after the end of the cold war has also deepened civil society's participation and engagement with the state in many parts of Africa. Unlike the withdrawal into narrow ethno-regional shell that characterized state-civil society relations in the past, there is more open and constructive engagement between the state and civil society in the contemporary period. The engagement of state and civil society in constructive interactions is also symptomatic of the prevailing liberal atmosphere provided by democratic governance. In many parts of Africa, civil society organizations are acting as watchdog to checkmate the excesses of the state and abuse of power.

Good governance must also be redefined in the African context. Components of good governance, such as macroeconomic stability, structural reform, administrative efficiency and transparency, social participation, do not necessarily coincide with the conditions needed for growth driven by trade and investment in the African continent. The most basic task for African countries is to establish a stable political regime and social unity, which are the preconditions of economic development. The urgent need in Africa is for home grown, creative solutions and breakthroughs in governance, science and technology, economic policies, curriculum, health and wellness, and just about any area of human existence.

\section{Conclusion}

The democratisation movement is one of the most defining features of the post-Cold War international order. Democratisation has transformed the political landscape of Africa dramatically and sit-tight dictators are the exceptions rather than the rule in contemporary African society. The democratisation movement has also thrown up new challenges and opportunities in Africa. The democratisation process needs patience, understanding and tolerance in seeking compromises with government. Current priority should be to obtain the relaxation of austerity measures and the provision of more economic assistance. It is not enough to include 
respect for human rights and the establishment of multi-party democracy as a new political conditionality in international and bilateral relations. There is a need also to support democratizing societies by economic measures to consolidate the democratic gains. Consolidation of current democratic gains also requires support for building political institutions, independent judiciary systems and training of political activists to create a critical mass of democracy activists. The weakness of civil institutions like the judiciary, the press, parliament, the police, and civil rights groups contributed largely to the resurgence of ethno-regional conflicts in the immediate, post-transitional period in many African states. There is therefore a need to strengthen these institutions by respecting their autonomy, devoid of state interference.

Concluding, successful democratisation does not imply that the state should retain exclusively control over the public-political sphere. Rather, it means that members of civil society organisations would continue to debate issues of common concern, assert new rights, and influence political and economic policy. Policy intervention on the part of civil society can be accomplished through the implementation of decentralised and autonomous programmes to supplement the role of the welfare state and through the design of non- bureaucratic forms of regulations to prevent the private sector from subordinating the economy to its interests. In addition, constructive engagement of fundamental ways of restructuring and devolving powers for the survival of the state needs to be facilitated. The need to recognise ethnic differences, the need to nurture ways of ensuring enduring cordial relations among the various nationalities cannot be overemphasised. As Africa marches on in democratic experience, the resolution of the national question will pave the way for democratic consolidation and the emergence of true nation-states.

\section{References:}

1. African Development Bank (2014) African Economic Outlook. Abidjan: African Development Bank

2. Adejumobi, Said (2000). 'Between Democracy and Development in Africa: What are the missing Links? , Paper presented to the World Bank Conference on 'Development Thinking in the Next Millennium', Paris, 26-28 June, 2000.

3. Ake, Claude (1996). Democracy and Development in Africa. Ibadan: Spectrum Books Limited.

4. Ake, Claude (1999). Quoted by Linda, J. Beck in Joseph, Richard (ed) State, Conflict, and Democracy in Africa. London: Lynne Rienner Publisher, 1999, p.210.

5. Ake, Claude. The Feasibility of Democracy in Africa (Dakar, Codesria 2000) 
6. Aleyomi, M.B. (2013) 'Africa and the Millennium Development Goals: Constraints and Possibilities’ International Journal of Politics and Good Governance 4 (4): 1-19

7. Barkan, J, D. (2009). Advancing Democratization in Africa: A chapter in the CSIS Africa

8. Program report: Africa Policy in the George W. Bush Years: Recommendations for the Obama Administration (January 2009)

9. Bendana, J. (2004) 'Good Governance and the MDGs: Contradictory or Complimentary' Paper Presented at the Institute for Global Network, Information and Studies (IGNIS) Conference”. Held on

10. September 20 at Oslo,Norway.

11. Bond, I.Margaret, H. and Hentz, J. (1999) 'Neo-colonialism and Neoliberalism in South Africa and

12. Zambia,” Political Science Quarterly 114 (3):479-502

13. Fantu, C. (2012) 'Democracy and People Power in Africa: still searching for the political Kingdom' Third World Quarterly, 33 (2): 265-291.

14. Fukuyama, Francis (1992). The End of History and the Last Man (New York: The Free Press.

15. Harrison, G. (2005). Economic faith, social project and a misreading of African society: The travails of neoliberalism in Africa. Third World Quarterly, 26(8), 1303-1320.

16. Higgott, R. (2005) 'The Theory and Practice of Global and Regional Governance: Accommodating American Exceptionalism and European Pluralism’ University of Warwick Garnet Working Paper 1 (5): $1-25$.

17. Howe, H. (2001) Ambiguous Order. Military Forces in African States. Boulder and London: Lynne Rienner.

18. Huntington, Samuel (1991).. The Third Wave: Democratization in the Late Twentieth Century. Oklahoma City: University of Oklahoma Press.

19. International Crisis Group (2004) 'Liberia and Sierra Leone: Rebuilding Failed States’, Africa Report, No. 87, 08 December 2004.

20. Mundy, K. (2007). Global Governance and Educational Change. Comparative Education, 43 (3), 339-357.

21. Nwabueze, B.O (1993). Democratisation. Ibadan: Spectrum Books Limited.

22. Olayode, K. (2013) 'Democratisation and the National Question in Nigeria (1999-2007)’ Contemporary Journal of African Studies 1 (2): 65-92 
23. Simelane, T. and Chiroro, B. (2013) 'Beyond the Millennium Development Goals: What can Africa

24. expect?'Africa Institute of South Africa Briefing No 84: 1-7 